\title{
Management of the Medical Record System at the Mother and Child Hospital (RSIA) Puri Bunda Malang City, East Java in 2019
}

\author{
Ema Novita Deniati ${ }^{1, *}$ Annisaa Annisaa ${ }^{2}$ \\ ${ }^{1,2}$ Department of Public Health, Faculty of Sport Science, Universitas Negeri Malang, Malang, East Java, Indonesia \\ *Corresponding author. Email: ema.deniati.fik@um.ac.id
}

\begin{abstract}
Medical records are very important in the process of patient data management in health care facilities. This study was conducted to identify the management of the medical record system at RSIA Puri Bunda Malang City. This qualitative research with a case study approach was done. Data were collected by interview and observation. Standard Operating Procedures for managing medical records at RSIA Puri Bunda are taken from the Minister of Health Regulation No. 269 of 2008. There is no special application for the implementation of medical records. The alignment system for medical record documents at the Puri Bunda Mother and Child Hospital uses SNF (Straight Numerical Filing). Destruction of medical records is in accordance with Permenkes No. 269 of 2008 article 8. Reporting of medical records for external is only reported to the Malang City Health Office. The recording of the medical record system uses semielectronic, namely by using Excel. The flow of medical record documents for outpatient treatment at RSIA Puri Bunda, namely (1) patients coming, (2) recording and inputting data, (3) filling in data by doctors, (4) inputting data by doctor assistants according to the coding book, (5) data provided to the medical record officer to be re-checked, (6) the filing section provides the new patient number in excel, lastly (7) the patient's file is entered in the storage bin.
\end{abstract}

Keywords: hospital, management, medical record, system

\section{INTRODUCTION}

Medical record personnel in the health care system have a very important role, especially in the aspect of data management or patient data processing, starting from patient registration, assembling, coding, indexing, and reporting. Every activity carried out by medical records personnel has a big role in presenting patient data accurately, accurately, in accordance with reality, and has the correct value. One of the activities in the medical record unit is reporting the daily inpatient census which is important to support the improvement of the system of a health service.

Medical records are important for further patient care, because complete data provides information in making the best decisions for treatment, treatment, medical action, and others. Furthermore, according to the Ministry of Health in 2006 stated that the medical record is a file that contains information about the patient's identity, history taking, physical laboratory determination, diagnosis of all medical services and actions provided to patients and treatment both inpatients, outpatients, and those receiving services. emergency department [1]. The contents of the patient's medical record generally include medical data or clinical data and non-medical data or sociological data. Clinical data consists of disease history, results of physical examination, diagnosis, treatment and results, reports from doctors, nurses, results of laboratory tests, x-rays and so on. Sociological data consists of identity data, socioeconomic data, addresses, and so on.

Medical records are used as a basis and guide for planning and analyzing diseases and planning treatment, care, and medical actions that must be given to patients [1]. Medical records can be used to improve the service quality of health facilities, protect medical personnel, and achieve optimal public health. Medical records contain various information on the chronological development of diseases, medical services, treatment, and medical actions that are useful as information material for the development of teaching and research in the field of medicine. The costs in the medical record can be used as a guide and material for determining financing in health services at health facilities. Medical records can be used 
as material for health statistics to study the development of public health and determine the number of sufferers of certain diseases. In addition, medical records can be the main evidence in resolving legal, disciplinary or ethical issues.

The development of health services has a close relationship with technological advances that are growing rapidly. The development of technology aims to facilitate human work, including in the health sector. In the development of information technology in the health sector, the use of web-based applications is increasingly popular because it can be run on any operating system and does not require high computer specifications. The use or implementation of a web-based information system application can be carried out in medical record reporting activities in hospitals. Through the web application, it is easier for medical record officers to carry out data management to produce accurate reporting data [2].

The data contained in the medical record includes the name, time, and signature of the medical officer who provided the service or action. However, if the medical record is done electronically, the signature of the medical officer is replaced by using a personal identity number or Personal Identification Number (PIN). Furthermore, if there is an error, the medical record data may not be deleted but changed by crossing out the error and affixing the signature of the officer concerned.

\section{METHOD}

This study uses a qualitative research method with a case study approach. Data was collected through interviews and observations. Observations were carried out for 3 days and interviews were carried out with resource persons, namely the Head of the Medical Record Installation at RSIA Puri Bunda.

\section{RESULTS AND DISCUSSION}

\subsection{Overview of RSIA Puri Bunda}

RSIA Puri Bunda under PT. Putraning Husada is located on Jl. North Sulfate Intersection No. 60A Malang, Pandanwangi Village, Blimbing District with a core service of polite, attentive, fast, precise and affordable, which is held in an integrated manner to achieve what the community needs. The location of the hospital which is located within the Malang City area and on an alternative route to the north of Malang allows RSIA Puri Bunda to reach the community both in the city and Malang district. The location of the hospital which is close to residential areas and villages causes RSIA Puri Bunda patients to vary greatly both in terms of education and income. Thus, RSIA Puri Bunda is obliged to provide comprehensive services and offer many options, especially for Family Planning services [3]
RSIA Puri Bunda has several services including general polyclinics, obstetrics and gynecology polyclinics, pediatric polyclinics, surgical polyclinics, dental conservation polyclinics, andrology polyclinics, internal medicine polyclinics, skin and genital polyclinics, radiology and clinical laboratories. RSIA Puri Bunda has 18 Specialist Doctors consisting of 8 Obstetrics Gynecology Specialists, 3 Pediatricians, 1 Surgeon, 1 Internal Medicine Specialist, 2 Anesthesiologists, Pathology Specialists 1 clinic, 1 person Andrology Specialist, 1 Dermatologist and Venereologist, and 3 Adult Dental Conservation Specialist Dentists. In addition, RSIA Puri Bunda also has 8 General Practitioners, 43 Midwives, 51 Nurses, 31 other Health Workers and 64 other Non-Medical Workers who are ready to serve patients wholeheartedly and always prioritize patient safety and comfort [3]

RSIA Puri Bunda has several main facilities, including a 24-hour emergency room, pharmacy installation, clinical laboratory, radiology, specialist doctor polyclinic, 4-dimensional ultrasound examination, delivery room, nursing room, and ambulance. In addition, RSIA has several inpatient facilities, namely, VIP treatment class, treatment class I, II and III, physiology baby care class and pathological baby care class [3].

With affordable prices and supported by the collaboration between RSIA Puri Bunda with several companies and insurance companies such as the Health Social Security Administration (BPJS), IM Care Insurance, Sinar Mas Insurance and Jaya Proteksi Insurance, it is hoped that RSIA Puri Bunda 8 patients will get maximum medical services with results as expected [3].

\subsection{Management of Medical Records at RSIA Puri Bunda}

\subsubsection{Standard Operating Procedures}

According to the informant, the SOP for managing medical records at the Puri Bunda Mother and Child Hospital was taken from the Minister of Health Regulation No. 269 of 2008 [4]. The policy of the Minister of Health was down to the policy of the Hospital or director and then down to the medical record installation, after that it became a guideline and could become an SOP.

\subsubsection{Medical Record Recording System}

The administration of medical records uses electronic information technology. According to the resource person, the medical record recording system at the Puri Bunda Mother and Child Hospital uses semi-electronic, namely using excel. Medical records at the Puri Bunda Mother and Child Hospital have 2 units, namely DPP and processing. DPP has used semi-computerization in 
entering patient data. Meanwhile, those who still use manual are the determination of RPCM and IMR (Incomplete Medical Record) and for DPJP it is electronic.

There is no special application for Medical Record Installation at the Puri Bunda Mother and Child Hospital. However, there is already a plan to make an application because it has been declared by the government to be paperless. The steps taken to realize paperless are by improving the system, for example, in the past, patient registration was still using excel but now it is using an application, so it is connected to the poly-poly. Prior to the application, the poly assistant must come to collect patient files. There is also an application for room transfers, so if a patient moves to a room, it will be tracked. But still not really focused on Medical Records.

\subsubsection{Medical Record Document Alignment System}

According to the resource person, the alignment system for medical record documents at the Puri Bunda Mother and Child Hospital uses SNF (Straight Numerical Filing), which is an alignment system based on the serial number of the patient who first came to the hospital, for example 000001, not based on year in order to avoid confusion for the system. One patient gets one number forever. There are no problems in sorting patient numbers. But in the storage of medical record files there are obstacles, namely the shelves that are not enough to accommodate medical record files. Efforts that have been made by the hospital are the destruction of numbers that are no longer active and are included in the new patient group in the medical record number. But the problem with changing this system is that the names of patients who are no longer active are not deleted, so that one number is owned by two patients. According to the resource person, there is actually no problem, but the problem is when inputting to BPJS.

Numbering errors that have occurred at the Puri Bunda Mother and Child Hospital, one of which is a patient who already has a card when visiting the hospital does not bring a card and is finally re-registered so that it has a new number because after being identified according to the date of birth the patient number was not found because the system or because of different patient writing. Then, a few days later the patient came back with a card and finally the patient had two numbers.

\subsubsection{Destruction of Medical Records}

According to the informant, the medical record storage rack is predicted to be full so that the efforts made to overcome the full medical record storage rack are the destruction of patients which includes retention. Retention is the period of time that must pass before a record can be deleted or deleted [5]. So, if the patient has been inactive for up to 5 years or has not visited the hospital for up to 5 years, it will be put into inactive, where in inactive there is an inactive room that is used to store patient files at the Puri Bunda Mother and Child Hospital who are no longer active in the hospital. 5 years after the last visit. However, if within 2 years after 5 years of inactivity the patient comes to visit, it can still become active again. However, if after 5 years of inactivity and after 2 years the total becomes 7 years after the last visit to the Puri Bunda Mother and Child Hospital, the patient does not visit again, the number will be inactivated and if the patient returns to the hospital after 7 years it will be given a new number. This is in accordance with the Minister of Health Regulation No. 269 of 2008 article 8, namely in article 8 the minimum storage limit is 5 years [4].

\subsubsection{Medical Record Personnel}

The number of medical record personnel at Puri Bunda Hospital is 12 people. In general, the duties of the medical record officer are at the TPP (Patient Reception Place) taking turns to accept outpatients and inpatients, the journey of inpatients from the patient to come home. Meanwhile, inpatients from patients come until they get a room, finish administration, and until the patient goes home. Meanwhile, the medical record personnel at the medical record installation are reporting, inputting outpatients and inpatients, and filling.

\subsubsection{Medical Record Reporting}

There are three types of medical record reporting at the Puri Bunda Mother and Child Hospital, namely monthly, annual, and periodic reports, and also in these three types there are two other types, including internal and external reports. Internal reports include monthly reports, temporary reports, and annual reports. Meanwhile, in external reports there are only annual reports. Reports for external reports will be submitted to the Malang Health Office, while internal reports will be reported to the director of the Puri Bunda Mother and Child Hospital.

\subsubsection{Recording of Medical Records}

According to sources, the recording for outpatient treatment takes the top 10 diseases, but from the medical record installation they cannot handle it because there are still system changes. This makes the medical record installation need the help of the IT team to retrieve or retrieve data on the top 10 diseases and also all input that the doctor's assistant sends to the medical record installation, for those who sort the top 10 new diseases, the medical records are sorted and the correct code is identified. Meanwhile, hospitalization for new and old patients is actually the same. So, even though the old patient visited 2 times, he was still given a new medical 
record file, but the number was fixed. Meanwhile, new patients are first given a new number and file, then they are given a blank file. Then by the officer, the patient's medical record file will be brought to the ER. Documents that have been submitted to the ER will be the duty of nurses and doctors to fill in.

The nurse brings to the file room when it's finished. On the day of KRS (hospital discharge), the distribution team from the medical record will retrieve the files stored in the file room, the files are retrieved within 2 times 24 hours. Once taken, the distribution team will input it in excel whose function is to see demographics, this demographic is to determine which area residents often visit the Puri Bunda Mother and Child Hospital, the patient's occupation, and so on. In addition to viewing demographics, this data also functions for external reports. If the patient is a BPJS patient, it will be entered into the BPJS, if not the BPJS will be assembled to see its completeness, if it is not complete then the head of the room or its members will be called to fill in. If everything is final, it will be entered into the filing.

\subsubsection{Monitoring and Evaluation}

According to resource persons, monitoring and evaluation of medical records is taken from indicators. There is LPCM, namely the completeness of the overall medical record for patients treated until the patient goes home. Then there is a high risk form which is usually used as an indicator, this is done every month and will be included in the internal report. Monitoring and evaluation of the completeness of medical records for hospitalized patients is carried out every day, while patients go home every month.

\subsubsection{Medical Record Document Flow}

According to the informant, the flow of medical record documents for outpatients is when a new patient arrives, recording and entering patient data, then verifying the truth and identifying its completeness. After that, the document will be brought by a doctor's assistant who will be filled in by the doctor after handling the patient. The input will be done by a doctor's assistant for diagnosis and the code for which a diagnostic coding book has been provided. The input is not carried out by medical record personnel because of the lack of human resources and the main duties of each medical record staff so that medical record personnel are assisted by doctor assistants for coding. When taking the document, the coding will be corrected again by the medical record officer to avoid errors in coding. After the assistant has finished coding the diagnosis, the file will be returned to the medical record at the TPP.

TPP will verify that the patient has visited. After completion of verification, the medical record document will be taken to the medical record storage area or to the medical record installation. After that, the filing section takes it to be entered into the number for the new patient in excel then the number will be verified, after verification it will be put on the shelf. As for the old patient from TPP, the card is seen, after that the TPP asks for a document request to the filing using a preset, the filing takes it and then it is verified that the document belongs to the patient or not, after it is confirmed that it belongs to the patient, it is lowered, and then the flow is the same as outpatient for new patients.

\subsubsection{Medical Record File}

According to sources, the color of the medical record file folder at the Puri Bunda Mother and Child Hospital has two colors, namely pink and green. Pink is for babies and children, while green is for adults. All patients, both old and new patients, received informed consent, because informed consent must be present in every patient. All actions taken by the doctor must have the consent of the patient. This is in line with the Regulation of the Minister of Health of the Republic of Indonesia Number 290 of 2008 [4]. If the patient wants to request a copy of the medical record resume, the patient is required to come to CS (Customer Service), and will be given an information document request form, after which the patient is given information to return after 3 times 24 hours to retrieve the summary results. The goal is to deal with incomplete resumes or no doctor's signature.

If you have finished writing the request for information, the CSO (Customer Service Office) will inform the medical record department to take his name on the 12 CSO (Customer Service Office) forms filled out by the patient. Once taken, the medical record officer will look for the patient's file. If it is not found within two days, it will be confirmed to the patient that the collection is carried out on the specified date. However, if it has been found, it is immediately given to the CSO (Customer Service Office) and by the medical record officer, a stamp has been received by the CSO (Customer Service Office), as evidence that the medical record officer has submitted it to the CSO (Customer Service Office). After that, the patient comes to take the summary. The flow is carried out if the patient requests the summary himself. But if it is not the patient himself, then he is required to use a power of attorney and attach an ID card because it belongs to the patient. This is in line with the Regulation of the Minister of Health of the Republic of Indonesia Number 269 of 2008, article 12 [4].

\section{CONCLUSION}

The medical record system is very important in data management or patient data processing, starting from patient registration, assembling, coding, indexing, and reporting. The medical record system at RSIA Puri 
Bunda uses SOPs in accordance with the provisions of the Minister of Health Regulation No. 269 of 2008 starting from patient registration, assembling, coding, indexing, and reporting. The recording of the medical record uses Ms. Excel. Monitoring and evaluation is done by looking at the high risk form which is usually used as an indicator, this is done every month and will be included in the internal report. Monitoring and evaluation of the completeness of medical records for hospitalized patients is carried out every day, while patients go home every month. The medical record file folder at the Puri Bunda Mother and Child Hospital has two colors, namely pink and green. Pink is for babies and children, while green is for adults. The flow of medical record documents for outpatient treatment at RSIA Puri Bunda, namely (1) patients coming, (2) recording and inputting data, (3) filling in data by doctors, (4) inputting data by doctor assistants according to the coding book, (5) data given to the medical record officer to be re-checked, (6) the filing section provides the new patient number in excel, lastly (7) the patient's file is entered in the storage rack.

\section{AUTHORS' CONTRIBUTIONS}

All authors (END and A) contributed in design, data collection, data analysis, and writing the manuscript.

\section{ACKNOWLEDGMENTS}

Thanks to RSIA Puri Bunda, Malang City East Java.

\section{REFERENCES}

[1] Ministry of Health Republic Indonesia. 2006. Pedoman Pengelolaan Rekam Medis Rumah Sakit di Indonesia. Jakarta: Direktorat Jenderal Pelayanan Medik

[2] Hatta, G. 2010. Pedoman Manajemen Informasi Kesehatan di Sarana Pelayanan Kesehatan. Jakarta: UI-Press

[3] RSIA Puri Bunda. 2019. RSIA Puri Bunda Malang, (Online), (http://puribundamalang.com/) diakses pada 18 November 2019

[4] Menteri Kesehatan Republik Indonesia. 2008. Peraturan Menteri Kesehatan RI No. 269 Tahun 2008 tentang rekam medis. Jakarta: Indonesia.

[5] Rustiyanto, E. dan W. A. R. (2011). Manajemen filing Dokumen Rekam Medis dan Informasi Kesehatan (Pertama). Yogyakarta 